\title{
DAMPAK KEBIJAKAN SUBSIDI PUPUK DAN HARGA PEMBELIAN PEMERINTAH TERHADAP KESEJAHTERAAN PRODUSEN DAN KON- SUMEN BERAS DI INDONESIA
}

\author{
Dahlia Nauly \\ Program Studi Agroteknologi, Fakultas Pertanian, \\ Universitas Muhammadiyah Jakarta \\ Jl. KH. Ahmad Dahlan Cireundeu, Ciputat - 15419, Indonesia \\ *Email : dahlia.nauly@yahoo.co.id
}

Diterima: 28/06/2019

Direvisi: 30/06/2019

Disetujui: 30/06/2019

\begin{abstract}
ABSTRAK
Kebijakan subsidi pupuk merupakan salah satu kebijakan yang penting di bidang pertanian di Indonesia. Selain itu, kebijakan yang dilakukan oleh pemerintah kebijakan Harga Pembelian Pemerintah (HPP). Kebijakan ini bertujuan ntuk melindungi petani dari jatuhnya harga gabah pada saat panen raya. Tulisan ini mengkaji dampak kebijakan subsidi pupuk dan HPP bagi produsen dan konsumen. Data yang digunakan adalah data time series tahunan dari tahun 1981 sampai 2014 dengan model ekonometrika persamaan simultan. Hasilnya menunjukkan bahwa surplus produsen dan surplus konsumen dipengaruhi oleh kondisi pasar beras domestik. Surplus produsen akan dicapai jika pemerintah menerapkan kebijakan jaminan harga berupa peningkatan Harga Pembelian Pemerintah (HPP), sedangkan surplus konsumen akan dicapai jika pemerintah menerapkan kebijakan peningkatan subsidi pupuk . Implikasi kebijakan yang disarankan bahwa untuk meningkatkan surplus produsen dan konsumen perlu diterapkan paket kebijakan yang merupakan kombinasi dari kebijakan peningkatan subsidi pupuk dan kebijakan peningkatan HPP, kebijakan tersebut tidak bisa diterapkan secara terpisah.
\end{abstract}

Kata kunci: subsidi pupuk, harga pembelian pemerintah, beras

\begin{abstract}
Fertilizer subsidy policy is one of the important policies in agriculture in Indonesia. In addition, policies implemented by the government Government Purchase Price policy (HPP). This policy aims to protect farmers from falling grain prices during the harvest. This paper examines the impact of fertilizer and HPP subsidy policies for producers and consumers. The data used are annual time series data from 1981 to 2014 with simultaneous equation econometric models. The results show that producer surplus and consumer surplus are influenced by domestic rice market conditions. The producer surplus will be achieved if the government implements a price guarantee policy in the form of an increase in Government Purchase Prices (HPP), while a consumer surplus will be achieved if the government implements a policy of increasing fertilizer subsidies. The policy implication is that to increase producer and consumer surplus, a policy package should be implemented which is a combination of policies to increase fertilizer subsidies and policies to increase HPP, the policy cannot be applied separately.
\end{abstract}

Keywords: fertilizer subsidies, government purchase prices (HPP), rice 


\section{PENDAHULUAN}

Sejak tahun 1969, kebijakan subsidi pupuk merupakan salah satu kebijakan yang menjadi tulang punggung kebijakan subsidi bidang pertanian di Indonesia. Pada tahun anggaran 2019, pagu subsidi pupuk sebanyak 9.550 .000 ton atau setara dengan $\mathrm{Rp} 29,9$ triliun baik untuk pupuk Urea, SP-36, ZA, NPK maupun organik (Anonim, 2019). Hal ini menunjukkan bahwa subsidi pupuk masih menjadi instrumen penting dalam kebijakan pertanian. Kebijakan pemerintah yang cenderung terus meningkatkan subsidi pupuk bertujuan untuk meningkatkan produksi sektor pertanian, khususnya subsektor tanaman pangan.

Kebijakan ini dilandasi pemikiran bahwa pupuk merupakan faktor kunci dalam meningkatkan produktivitas, adanya subsidi menjadikan harga pupuk lebih murah sehingga mendorong peningkatan penggunaan input tersebut (PSE-KP 2009). Selain itu, subsidi pupuk bertujuan untuk merespons kecenderungan kenaikan harga pupuk di pasar internasional dan penurunan tingkat keuntungan usaha tani (PSE-KP 2006). Subsidi pupuk diharapkan dapat meningkatkan produktivitas pertanian dan kesejahteraan petani. Namun demikian, kebijakan subsidi pupuk ternyata masih mengundang perdebatan. Di satu sisi, kebijakan subsidi pupuk dinilai berdampak positif terhadap peningkatan produktivitas sektor pertanian dan pendapatan petani, khususnya tanaman pangan. Hal ini antara lain disebutkan dalam hasil kajian Syafa'at et al. (2006), PSE-KP (2009), Hutagaol et al. (2009), dan World Bank (2009b). Penelitian lain menyatakan bahwa kebijakan subsidi pupuk tidak efektif dalam hal biaya, pencapaian petani target, kurang tepat waktu dan harga, bahkan cenderung mendorong penggunaan pupuk yang berlebihan. Argumentasi tersebut antara lain disebutkan oleh Herman et al. (2005), Syafa' at et al. (2006), Sjari (2007), PSEKP (2009), dan World Bank (2009a).
Selain subsidi pupuk, kebijakan yang telah dilakukan oleh pemerintah adalah penjaminan harga gabah melalui kebijakan Harga Pembelian Pemerintah (HPP). Kebijakan ini bertujuan ntuk melindungi petani dari jatuhnya harga gabah pada saat panen raya. Selain itu menjadi insentif bagi petani untuk tetap memproduksi bahan pangan (khususnya beras) di dalam mendukung terwujudnya ketahanan pangan nasional.

Dengan mempertimbangkan isu yang masih diperdebatkan tersebut tulisan ini mengkaji dampak kebijakan subsidi pupuk dan HPP bagi produsen dan konsumen. Komoditi beras digunakan karena beras adalah komoditas penting dan strategis di Indonesia. Hasil kajian diharapkan dapat menjadi masukan pilihan kebijakan yang relevan. Berdasarkan permasalahan yang telah dirumuskan maka tujuan makalah ini adalah menganalisis dampak kebijakan subsidi pupuk dan HPP terhadap kesejahteraan produsen dan konsumen beras di Indonesia.

\section{METODE}

Jenis data yang digunakan adalah data time series tahunan dari tahun 1981 sampai 2014. Data yang digunakan bersumber dari beberapa instansi terkait yaitu Badan Pusat Statistik (BPS), Badan Urusan Logistik (Bulog), Kementerian Perdagangan, dan Kementerian Pertanian.

Tulisan ini menggunakan model ekonometrika. Model ekonometrika merupakan gambaran dari hubungan masing-masing variabel penjelas (explanatory variables) terhadap variabel endogen (dependent variables) khususnya yang menyangkut tanda dan besaran (magnitude and sign) dari parameter dugaan sesuai dengan harapan teoritis secara apriori (Koutsoyannis 1977). Model yang dibangun merupakan model persamaan simultan, yaitu sebagai berikut: 


\section{Areal Panen}

Areal panen merupakan fungsi dari harga gabah tingkat petani, harga pupuk urea riil, perubahan kredit pertanian, harga benih riil, luas areal irigasi, curah hujan, dan areal panen tahun sebelumnya. Secara matematis persamaan produksi padi dapat dirumuskan :

$$
\begin{aligned}
& A P=a_{0}+a_{1} H G T P R_{t}+a_{2} H P U R_{t} \\
& + \\
& a_{3} K D P R_{t}+a_{4} H B N R_{t}+a_{5} \\
& U P T K R_{t}+a_{6} A I_{t}+a_{7} C_{t}+ \\
& a 8 \\
& A P_{t-1} \ldots .1
\end{aligned}
$$

APt (luas areal panen pada tahun dalam ribu ha), HGTPRt (harga gabah riil di tingkat petani tahun dalam $\mathrm{Rp} / \mathrm{Kg}$ ), HPURt (harga pupuk urea riil dalam $\mathrm{Rp} / \mathrm{Kg}$ ), $K D P R_{t}$ (kredit pertanian riil dalam $\mathrm{Rp} / \mathrm{Kg}$ ), $H B N R_{t}$ (harga benih riil dalam $\mathrm{Rp} / \mathrm{Kg}$ ), UPTKRt (upah tenaga kerja riil dalam $\mathrm{Rp}$ ), AIt (luas areal irigasi dalam ribu ha), $\mathrm{CH}_{t}=$ Curah hujan dalam $\mathrm{mm} / \mathrm{ta}-$ hun), $\mathrm{A} P_{t-1}$ (luas areal panen dalam ribu ton) dan $u_{1}$ (error term) Tanda dan besaran parameter yang diharapkan adalah : $a_{1}, a_{3}, a_{6}, a_{7}>0$; $a_{2}, a_{4}, a_{5},<0 ; 0<a_{8}<1$.

\section{Produksi Padi}

Produksi padi merupakan perkalian antara areal panen dan produktivitas. Secara matematis persamaan produksi padi dirumuskan:

$$
P P_{t}=A P_{t}{ }^{*} P T V_{t}
$$$$
\text { …... } 2
$$

dimana:

$P P_{t}$ (produksi padi dalam ribu ton), APt (luas areal panen dalam ribu ha)

dan PTV( produktivitas padi dalam ton/ha).

\section{Produksi Beras}

Produksi beras merupakan perkalian antara produksi padi dengan faktor konversi. Faktor konversi yang digunakan dalam penelitian ini adalah 0,63 sesuai dengan pendekatan yang digunakan oleh Badan Pusat Statistik tahun 1997-2005. Secara matematis persamaan produksi beras dirumuskan:

$P B_{t}=P P_{t} * \mathrm{KO}_{t}$

...... 3

dimana:

$P B_{t}$ (produksi beras dalam ribu ton), $P P_{t}$ (produksi padi dalam ribu ton) dan $\mathrm{KO}_{t}$ (faktor konversi).

\section{Stok Beras}

Stok beras merupakan salah satu komponen yang dapat mempengaruhi harga. Persamaan stok beras Indonesia dipengaruhi oleh beberapa faktor yaitu harga beras eceran, operasi pasar, jumlah impor beras, dan jumlah stok beras tahun lalu. Persamaannya adalah: $S T B_{t}=\mathrm{b}_{0}+\mathrm{b}_{1} H B E R_{t}+\mathrm{b}_{2} O P_{t}+\mathrm{b}_{3}$ $J I B_{t}+\mathrm{b}_{4} S T B_{t-1}+u_{2} \quad \ldots$. 4

dimana

$S T B_{t}$ (stok beras dalam ribu ton) $H B E R_{t}$ (harga beras eceran riil dalam $\mathrm{Rp} / \mathrm{Kg}$ ), $O P_{t}$ (operasi pasar beras dalam ribu ton), $J I B_{t}$ (jumlah impor beras pada tahun dalam ribu ton), $S B_{t-1} \quad$ (stok beras pada tahun sebelumnya dalam ribu ton) dan $u_{2}$ (error term) Tanda dan besaran parameter yang diharapkan adalah :

$\mathrm{b}_{1}, \mathrm{~b}_{2}<0 ; \mathrm{b}_{3}>0 ; 0<\mathrm{b}_{4}<1$.

\section{Penawaran Beras}

Penawaran beras Indonesia merupakan persamaan identitas dari penjumlahan produksi beras, stok beras awal tahun, dan jumlah impor beras. Variabel ekspor tidak dimasukan di dalam persamaan identitas penawaran beras karena jumlah ekspor 
beras yang sangat sedikit. Persamaan penawaan beras Indonesia adalah:

$S B I_{t}=P B_{t}+S T B_{t-1}+J I B_{t}$

..... 5

dimana:

$S B I_{t}$ (penawaran beras Indonesia dalam ribu ton) dan $P B_{t}$ (produksi beras Indonesia dalam ribu ton), $S T B_{t-1}$ (stok beras di Indonesia pada tahun sebelumnya dalam ribu ton) dan $J I B_{t}$ (total jumlah impor beras Indonesia dalam ribu ton)

\section{Permintaan Beras}

Permintaan beras Indonesia dipengaruhi oleh harga beras eceran, harga barang lain (komoditas jagung sebagai komoditas substitusi), GDP riil, jumlah penduduk, dan permintaan beras tahun lalu.

$D B_{t}=\mathrm{c}_{0}+\mathrm{c}_{1} H B E R_{t}+\mathrm{c}_{2} H J E R_{t}+\mathrm{c}_{3}$ $G D P R_{t}+\mathrm{c}_{4} J P I t+\mathrm{c}_{5} D B I t-1$ $+u_{3}$

dimana

$D B_{t}$ (pemintaan beras di Indonesia dalam ribu ton), $H B E R_{t}$ (harga beras eceran dalam $\mathrm{Rp} / \mathrm{Kg}$ ), $H_{J E R_{t}}$ (harga jagung eceran riil dalam $\mathrm{Rp} / \mathrm{Kg}$ ), GDPRt (GDP riil Indonesia dalam US\$), JPIt (jumlah penduduk dalam ribu jiwa), $D B_{t-1}$ (permintaan beras di Indonesia dalam ribu ton) dan $u 6$ (error term)

Tanda dan besaran parameter yang diharapkan adalah :

$\mathrm{c}_{1}<0 ; \mathrm{c}_{2}, \mathrm{c}_{3}, \mathrm{c}_{4}>0 ; 0<\mathrm{c}_{5}<1$.

\section{Harga Impor Beras}

Harga impor beras Indonesia dipengaruh oleh harga beras dunia, nilai tukar Indonesia, dan harga impor beras Indonesia tahun lalu. Persamaan harga impor

beras Indonesia adalah:

$H I B R_{t}=\mathrm{d}_{0}+\mathrm{d}_{1} H B D R_{t}+\mathrm{d}_{2} N T R_{t}+$ $\mathrm{d}_{3} T I R_{t-1}+\mathrm{d}_{4} H_{I B R} R_{t-1}+u_{4}$

dimana
$H I B R_{t}$ (harga impor beras riil Indonesia dalamUS $\$ / \mathrm{kg}$ ), $\quad H B$ (harga beras dunia riil dalam US $\$ / \mathrm{kg}$ ), NTRt (nilai tukar riil Indonesia dalam Rp/US\$), TIR ${ }_{t-1}$ (tarif impor beras Indonesia tahun sebelumnya dalam $\mathrm{Rp} / \mathrm{Kg}$ ), $H I B R$ $t_{t-1}$ (harga impor beras riil Indonesia tahun sebelumnya dala$\mathrm{mUS} \$ / \mathrm{kg}$ ) dan $u_{4}$ (error term)

Tanda dan besaran parameter yang diharapkan adalah :

$\mathrm{d}_{1}, \mathrm{~d}_{3}>0 ; \mathrm{d}_{2}<0,0<\mathrm{d}_{4}<1$.

\section{Harga Beras Eceran}

Harga eceran beras Indonesia dipengaruhi oleh harga impor beras Indonesia, permintaan beras Indonesia, harga gabah tingkat petani, permintaan, penawaran beras Indonesia, trend waktu, dan harga beras eceran tahun lalu. Persamaan harga eceran beras Indonesia:

$$
\begin{aligned}
H B E R_{t}= & \mathrm{e}_{0}+\mathrm{e}_{1} H I B R_{t}+\mathrm{e}_{2} H G T P R_{t} \\
& +\mathrm{e}_{3} D B_{t}+\mathrm{e}_{4} S B I_{t-1}+\mathrm{e}_{5} \\
& T I_{t}+ \\
& \mathrm{e}_{6} H B E R_{t-1}+u_{5}
\end{aligned}
$$

dimana

$H B E R_{t}$ (harga beras eceran riil dalam $\mathrm{Rp} / \mathrm{kg}$ ), HIBRt (harga impor beras riil dalam US $\$ / \mathrm{kg}$ ), HGTPRt (harga gabah tingkat petani riil dalam $\mathrm{Rp} / \mathrm{kg}), D B_{t}$ (permintaan beras Indonesia dalam ribu ton), $S B_{t-1}$ (penawaran beras Indonesia dalam ribu ton), $T I_{t}$ (trend Indonesia), HBER ${ }_{t-1}$ (harga beras eceran riil di Indonesia tahun sebelumnya dalam US $\$ / \mathrm{kg}$ ) dan $u 8$ (error term)

Tanda dan besaran parameter yang diharapkan adalah :

$\mathrm{e}_{1}, \mathrm{e}_{2}, \mathrm{e}_{3}, \mathrm{e}_{5}>0 ; \mathrm{e}_{4}<0 ; 0<\mathrm{e}_{6}<1$.

\section{Harga Gabah Tingkat Petani}

Harga gabah di tingkat petani secara nasional dijadikan sebagai variabel endogen. Harga gabah tingkat petani, selain ditentukan oleh trend Harga Pembelian Pemerintah 
(HPP), juga diduga dipengaruhi oleh harga beras eceran, perubahan produksi padi, dan harga gabah di tingkat petani tahun sebelumnya. $H G T P R_{t}=\mathrm{f}_{0}+\mathrm{f}_{1} H B E R_{t}+\mathrm{f}_{2} H P P R_{t}$ $+\mathrm{f}_{3}\left(P P_{t}-P P_{t-1}\right)+\mathrm{f}_{4}$ HGTPR $t^{-1}+u_{6}$ .... 9

dimana

HGT (harga gabah di tingkat petani riil dalam $\mathrm{Rp} / \mathrm{Kg}$ ), $H B E R t$ (harga beras eceran riil dalam $\mathrm{Rp} / \mathrm{Kg}$ ), HPPRt (harga pembelian pemerintah riil dalam $\mathrm{Rp} / \mathrm{Kg}$ ), $P P_{t}$ (produksi padi Indonesia dalam ribu ton), HGTPR ${ }_{t-1}$ (harga gabah tingkat petani riil tahun sebelumnya dalam $\mathrm{Rp} / \mathrm{Kg}$ ) dan $u_{6}$ (error term)

Tanda dan besaran parameter yang diharapkan adalah :

$\mathrm{f}_{1}, \mathrm{f}_{2}>0 ; \mathrm{f}_{3}<0 ; 0<\mathrm{f}_{4}<1$.

\section{Identifikasi dan Estimasi Model}

Menurut Koutsoyiannis (1977), terdapat dua tahap identifikasi terhadap suatu model persamaan simultan yaitu: Order Condition dan Rank condition. Order condition digunakan untuk mengetahui apakah persamaan yang ada dapat diidentifikasi atau tidak. Langkah dalam penentuan order condition yaitu :

a. Bila $(\mathrm{K}-\mathrm{M}) \geq(\mathrm{G}-1)$, maka persamaan tersebut dapat diidentifikasi

b. Bila $(\mathrm{K}-\mathrm{M})<(\mathrm{G}-1)$, maka persamaan tersebut tidak dapat diidentifikasi atau unidentified. $\mathrm{K}$ adalah total variabel dalam model (variabel endogen dan predetermined), $\mathrm{M}$ adalah total variabel endogen dan eksogen dalam persamaan yang akan diidentifikasi dan $\mathrm{G}$ adalah total persamaan dalam model.

Rank condition digunakan untuk mengidentifikasi persamaan setelah uji order condition menghasilkan kesimpulan dapat diidentifikasi. Uji rank condition dilakukan untuk melihat persamaan tersebut exactly identified atau overidentified. Persamaan tersebut $e x$ actly identified, bila $(\mathrm{K}-\mathrm{M})=(\mathrm{G}-1)$ dan
Persamaan tersebut overidentified, bila $(\mathrm{K}-\mathrm{M})>(\mathrm{G}-1)$.

Model yang digunakan terdiri dari 9 persamaan (tiga persamaan identitas dan enam persamaan struktural). Model ini terdiri dari 9 variabel endogen (G). Jumlah variabel yang paling banyak dalam suatu persamaan adalah lima variabel (M). Berdasarkan kriteria order condition $(\mathrm{K}-\mathrm{M})>(\mathrm{G}-1)$, maka dapat disimpulkan bahwa semua persamaan struktural yang terdapat dalam model adalah over identified, sehingga parameter diestimasi menggunakan metode Two Stage Least Squares (2SLS). Pengolahan data menggunakan Software Statistical Analysis System/Econometric Time Series (SAS/ETS) versi 9.3.

\section{Uji Statistik}

\section{Uji Statistik-F}

Pengujian terhadap estimasi persamaan secara keseluruhan dapat dilakukan dengan menggunakan uji statistik-F. Uji F dapat menjelaskan kemampuan variabel eksogen secara bersamasama dalam menjelaskan keragaman dari variabel endogen.

Hipotesis:

$\mathrm{H}_{0}: \beta 1=\beta 2=\ldots . .=\beta \mathrm{j}=0$

$\mathrm{H}_{1}$ : minimal ada satu $\beta \mathrm{j} \neq 0$

dimana:

$\mathrm{j}=1,2,3, \ldots, \mathrm{n}$

$\mathrm{n}=$ banyaknya variabel penjelas dalam suatu persamaan

\section{Uji Statistik-t}

Uji parsial (uji t) bertujuan untuk mengetahui apakah variabel eksogen yang terdapat di dalam model secara individu berpengaruh nyata terhadap variabel endogen.

Hipotesis:

$\mathrm{H}_{0}: \beta_{\mathrm{j}}=0$

$\mathrm{H}_{1}$ : uji satu arah $\beta \mathrm{j}>0$ atau $\beta \mathrm{j}<0$

Kriteria uji:

1. $\mathrm{H}_{1}: \beta_{\mathrm{j}}>0$, bila P-value uji statistik-t

$<\alpha$ maka tolak $\mathrm{H}_{0}$

2. $\mathrm{H}_{1}: \beta_{\mathrm{j}}<0$, bila P-value uji statistik-t

$<\alpha$ maka tolak $\mathrm{H}_{0}$ 
Tulisan ini menggunakan uji satu arah dengan taraf $\alpha$ sebesar 15 persen, sehingga apabila $\mathrm{P}$-value uji statistik-t $<$ $\alpha$ sebesar 15 persen maka tolak $\mathrm{H}_{0}$. Hal ini berarti bahwa variabel penjelas berpengaruh secara nyata terhadap variabel endogennya. Pada output Software SAS, Nilai Pr merupakan probabilitas untuk uji dua arah, sehingga untuk pengujian satu arah nilai probabilitas harus dibagi dua.

\section{Uji Statistik Durbin-h}

Uji statistik Durbin-h (Dh) digunakan untuk mengetahui ada tidaknya serial korelasi pada persamaan yang mengandung variabel bedakala dengan rumus berikut (Pindyck dan Rubinfeld, 1998):

$D h=\left(1-\frac{D w}{2}\right)\left(\sqrt{\frac{N}{1-N(\operatorname{Var} \beta)}}\right)$

dimana:

$\mathrm{Dh}=$ Nilai statistik durbin-h

Dw $=$ Nilai Durbin Watson

$\mathrm{N}=$ Jumlah periode pengamatan

$\operatorname{Var} \beta=$ Varians variabel bedakala endogen $(\mathrm{SE})^{2}$

Apabila digunakan taraf $\alpha=5$ persen, sehingga diketahui $-1.96 \leq \mathrm{Dh} \leq 1.96$, maka dapat disimpulkan persamaan tidak mengalami masalah serial korelasi. Namun apabila diketahui nilai $\mathrm{Dh}<$ 1.96 maka terdapat serial korelasi negatif, sebaliknya apabila nilai $\mathrm{Dh}>$ 1.96 maka terdapat serial korelasi positif.

\section{Uji Multicollinearity}

Multicollinearity adalah suatu hubungan linier antara dua atau lebih variabel penjelas dalam suatu persamaan tertentu. Jika terjadi korelasi yang sempurna diantara sesama variabel penjelas maka koefisien parameter menjadi tidak dapat ditaksir dan nilai standard error setiap koefisien estimasi menjadi tidak terhingga (Sitepu dan Sinaga, 2006). Salah satu cara untuk menentukan masalah multicollinearity dapat dilihat dari nilai Variance Inflation Factor (VIF). Pada umumnya masalah multicollinearity yang serius terjadi apabila nilai VIF dari suatu variabel lebih besar dari 10 (Widarjono, 2007).

\section{Validasi Model}

Validasi suatu model dilakukan untuk melihat keragaman antara kondisi aktual dengan hasil simulasi. Validasi model persamaan simultan menggunakan solusi metode newton. Validasi juga untuk melihat seberapa valid suatu persamaan digunakan untuk menganalisis suatu persoalan. Validasi suatu model biasanya dilihat dari beberapa parameter yang digunakan sebagai indikasi validitas suatu model persamaan simultan.

Indikator statistik yang digunakan untuk validasi model adalah Root Means Squares Percent Error (RMSPE) dan Theil Inequality (U-Theil) serta dekomposisinya. RMSPE digunakan untuk mengukur seberapa dekat nilai-nilai dugaan itu mengikuti nilai aktual. UTheil digunakan untuk mengukur daya prediksi model, selang nilainya dari 0-1. Model yang baik akan mendekati nilai nol, sebaliknya jika mendekati satu model dianggap kurang dapat menjelaskan data yang sebenarnya. Evaluasi terhadap daya prediksi suatu model (model validation) dilakukan untuk mengetahui kualitas model dalam memprediksi perilaku data aktual yang digunakan dalam suatu model (Nugroho, 2014).

Perhitungan validasi sebagai berikut (Pindyck dan Rubinfield, 1991):

$$
\begin{aligned}
& \begin{array}{c}
R M S E=\sqrt{\frac{1}{n} \sum_{t=1}^{n}\left(Y_{t}^{s}-Y_{t}^{a}\right)^{2}} \\
R M S P E=\sqrt{\frac{1}{n} \sum_{t=1}^{n}\left(\frac{Y_{t}^{s}-Y_{t}^{a}}{Y_{t}^{a}} x 100\right)^{2}}
\end{array} \\
& U=\frac{\sqrt{\frac{1}{n} \sum_{t=1}^{n}\left(Y_{t}^{S}-Y_{t}^{a}\right)^{2}}}{}
\end{aligned}
$$


$Y_{t}^{a}=$ Nilai aktual variabel endogen

$\mathrm{t}=$ Jumlah periode simulasi $(1,2,3, \ldots$,

n)

\section{Simulasi Model}

Analisis simulasi digunakan untuk mengukur dampak perubahan variabel eksogen. Periode simulasi dalam penelitian ini adalah periode historis yaitu dari tahun 2010-2014. Rentang simulasi historis bertujuan untuk mengevaluasi dampak kebijakan subsidi pupuk terhadap permintaan dan penawaran beras. Simulasi yang dilakukan dalam penelitian ini dilakukan pada subsidi pupuk dan harga pembelian pemerintah (HPP), yaitu:

S1: peningkatan subsidi pupuk urea $10 \%$

S2: peningkatan HPP $10 \%$

S3:peningkatan HPP 5\% dan subsidi pupuk urea $5 \%$.

\section{Analisis Perubahan Indikator Kese- jahteraan}

Surplus produsen dan konsumen menunjukan tingkat kesejahteraan masyarakat dan merupakan indikator penentu arah kebijakan yang dilakukan. Perubahan kesejahteraan dapat dihitung dengan rumus sebagai berikut:

1. Perubahan Surplus Produsen Beras $\mathrm{PB}_{\mathrm{A}}\left(\mathrm{HGTPR}_{\mathrm{B}}-\mathrm{HGTPR}_{\mathrm{A}}\right)+1 / 2$ $\left(\mathrm{PB}_{\mathrm{B}}-\mathrm{PB}_{\mathrm{A}}\right)\left(\mathrm{HGTPR}_{\mathrm{A}}-\mathrm{HGTPR}_{\mathrm{B}}\right)$

2. Perubahan Surplus Konsumen Beras

$\mathrm{DB}_{\mathrm{A}}\left(\mathrm{HBER}_{\mathrm{B}}-\mathrm{HBER}_{\mathrm{A}}\right)+1 / 2\left(\mathrm{DB}_{\mathrm{B}}\right.$ - DB $\left._{\mathrm{A}}\right)\left(\mathrm{HBER}_{\mathrm{B}}-\mathrm{HBER}_{\mathrm{A}}\right)$

3. Net Surplus $=$ Perubahan surplus produsen + Perubahan surplus konsumen

$A=$ Nilai dasar

$\mathrm{B}=$ Nilai simulasi

\section{HASIL DAN PEMBAHASAN}

Tulisan ini menggunakan model simultan dinamis yang dibangun dari lima persamaan struktural dan tiga persamaan identitas. Menurut Koutsoyiannis (1977), model yang baik harus dapat memenuhi kriteria ekonomi, kriteria statistik, dan kriteria ekonometrika. Berdasarkan kriteria ekonomi, semua variabel penjelas telah menunjukan tanda parameter estimasi yang sesuai dengan harapan (hipotesis) dan logis dari sudut pandang ekonomi.

Berdasarkan kriteria statistik, nilai penyesuaian koefisien determinasi (adjusted $R^{2}$ ) secara umum cukup tinggi. Sebagian besar mempunyai nilai $\mathrm{R}^{2}$ diatas 90 persen. Kemudian apabila dilihat dari nilai peluang uji statistik-F, 80 persen persamaan memiliki nilai peluang uji statistik-F yang lebih kecil dari taraf $\alpha=0.05$. Berdasarkan kriteria ekonometrika, hasil uji statistik durbinw (Dw) didapatkan kisaran nilai 1.96 sampai 2.56. Hal itu menunjukkan bahwa semua persamaan tidak mengalami masalah serial korelasi. Selain itu, hasil uji multicollinearity menunjukan bahwa seluruh variabel penjelas yang terdapat dalam masing-masing persamaan struktural lebih kecil dari 10, sehingga dapat disimpulkan bahwa model yang dibangun tidak memiliki masalah multicollinearity yang serius.

Berdasarkan kriteria-kriteria tersebut dan juga mempertimbangkan rentang periode pengamatan yang relatif panjang maka hasil pendugaan model cukup representatif dalam menggambarkan fenomena ekonomi beras Indonesia. Hasil identifikasi model menunjukkan bahwa seluruh persamaan dalam model overidentified. Hasil estimasi model keragaan ekonomi beras dapat dilihat pada Tabel 1. 
Tabel 1. Hasil Estimasi

\begin{tabular}{lccc}
\hline \multicolumn{1}{c}{ Persamaan Struktural } & Prob $>\mathrm{F}$ & $\mathrm{R}^{2}-\mathrm{Adj}$ & $\mathrm{DW}$ \\
\hline Luas areal panen & $<0.0001$ & 0.944 & 2.298 \\
Stok beras Indonesia & 0.5786 & 0.134 & 1.961 \\
Permintaan beras & $<0.0001$ & 0.956 & 2.119 \\
Harga gabah di tingkat petani & $<0.0001$ & 0.947 & 2.212 \\
Harga impor beras & $<0.0001$ & 0.959 & 2.522 \\
Harga beras eceran & $<0.0001$ & 0.945 & 1.646 \\
\hline
\end{tabular}

\section{Faktor-faktor yang Mempengaruhi Permintaan dan Penawaran Beras}

\section{Luas Areal Panen Padi Indonesia}

Hasil estimasi peubah yang mempengaruhi luas area panen padi di Indonesia dapat dilihat pada Tabel 2. Berdasarkan analisis dari model yang digunakan, variabel harga gabah di tingkat petani, harga pupuk urea, besarnya kredit pertanian, harga benih padi, upah tenaga kerja, luas areal irigasi, curah hujan dan luas areal panen padi tahun sebelumnya secara bersama-sama mempengaruhi luas area panen padi. Harga pupuk urea, harga benih padi dan upah tenaga kerja berpengaruh negatif terhadap luas areal padi Indonesia. Sedangkan harga gabah di tingkat petani, kredit pertanian, luas areal irigasi, curah hujan dan luas areal panen padi tahun sebelumnya berpengaruh positif pada luas areal padi.

Tabel 2. Hasil Estimasi Parameter Luas Areal Padi Indonesia

\begin{tabular}{lrr}
\hline Variabel & $\begin{array}{c}\text { Parameter } \\
\text { Estimasi }\end{array}$ & Prob $>|t|$ \\
\hline Intersep & -381.675 & 0.811 \\
HGTPR & 0.446 & 0.078 \\
HPUR & -0.081 & 0.731 \\
KDPR & 0.003 & 0.358 \\
HBNR & -0.097 & 0.408 \\
UPTKR & -0.038 & 0.133 \\
AI & 0.639 & 0.157 \\
CH & 0.255 & 0.190 \\
LAP & 0.696 & 0.0003 \\
\hline Prob $>F:<0.0001$ & $\mathrm{R}^{2}: 0.959$ \\
DW $=2.297$ & & \\
\hline
\end{tabular}

\section{Stok Beras Indonesia}

Hasil estimasi persamaan stok beras Indonesia mempunyai nilai $\mathrm{R}^{2}$ yang rendah yaitu yaitu 0.13 (Tabel 3 ). Stok beras yang dikaji pada penelitian ini merupakan stok beras yang ada di Bulog. Hal tersebut dilakukan karena terkait dengan kelengkapan data dan melihat fungsi Bulog dalam menjaga kestabilan ketersediaan beras. Oleh sebab itu jumlah beras yang ada di masyarakat tidak diperhitungkan. Hal ini menunjukan bahwa 13 persen stok beras Indonesia dapat dijelaskan oleh variabel-variabel harga beras eceran, pengadaan beras, operasi pasar, impor beras dan stok beras tahun sebelumnya. Harga beras eceran dan operasi pasar berpengaruh terhadap stok beras Indonesia dengan arah negatif. Pengadaan beras Indonesia kurang responsif terhadap stok beras dalam jangka pendek.

Tabel 3. Hasil Estimasi Parameter Stok Beras Indonesia

\begin{tabular}{lrl}
\hline Variabel & $\begin{array}{c}\text { Parameter } \\
\text { Estimasi }\end{array}$ & Prob $>|\mathrm{t}|$ \\
\hline Intersep & 1210.883 & 0.007 \\
HBER & -0.039 & 0.533 \\
PGB & 0.208 & 0.123 \\
OP & -0.000 & 0.821 \\
JIB & 0.116 & 0.332 \\
LSTB & 0.0251 & 0.896 \\
\hline Prob > F : 0.77 & & DW:1.961 \\
& & $\mathrm{R}^{2}: 0.134$ \\
\hline
\end{tabular}

\section{Permintaan Beras Indonesia}

Hasil estimasi persamaan permintaan beras Indonesia disajikan pada Tabel 4. Nilai $\mathrm{R}^{2}$ menunjukan bahwa 96 persen variasi permintaan beras Indonesia dapat dijelaskan oleh variabel harga beras eceran, harga jagung eceran, GDP, jumlah penduduk dan permintaan beras Indonesia tahun lalu. Harga jagung eceran mempengaruhi permintaan beras dengan arah positif. Hal ini berarti jagung dan beras saling bersubtitusi. Sedangkan 
harga beras eceran berpengaruh negatif pada permintaan beras Indonesia. Hal ini berarti jika harga beras eceran meningkat maka permintaan beras akan mengalami penurunan. Perubahan pendapatan nasional Indonesia dan jumlah penduduk Indonesia juga berpengaruh terhadap permintaan beras Indonesia dengan arah positif. Hal ini menunjukan bahwa peningkatan jumlah pendapatan nasional dan jumlah penduduk Indonesia akan meningkatkan permintaan beras Indonesia.

Tabel 4. Hasil Estimasi Permintaan Beras Indonesia

\begin{tabular}{lrc}
\hline Variabel & $\begin{array}{c}\text { Parameter } \\
\text { Estimasi }\end{array}$ & Prob $>|\mathrm{t}|$ \\
\hline Intersep & -10557.1 & 0.008 \\
HBER & -0.422 & 0.175 \\
HJER & 0.440 & 0.581 \\
GDPR & 0.376 & 0.046 \\
JPI & 0.147 & 0.000 \\
LDB & 0.349 & 0.042 \\
\hline \multicolumn{2}{l}{ Prob > F : <0.0001 } & DW:2.119 \\
& & $\mathrm{R}^{2}: 0.963$ \\
\hline
\end{tabular}

\section{Harga Gabah Tingkat Petani}

Persamaan harga gabah di tingkat petani mempunyai nilai $\mathrm{R}^{2}$ yang cukup tinggi yaitu 0.95 (Tabel 5). Hal ini menunjukan bahwa 95 persen variasi harga gabah di tingkat petani dapat dijelaskan oleh variabel harga beras eceran, tren harga pembelian pemerintah, selisih produksi padi dan harga gabah di tingkat petani tahun sebelumnya. Selisih produksi padi memiliki hubungan negatif.

Tabel 5. Hasil Estimasi Parameter Harga Gabah Tingkat Petani

\begin{tabular}{lrr} 
Variabel & $\begin{array}{r}\text { Parameter } \\
\text { Estimasi }\end{array}$ & Prob $>|\mathrm{t}|$ \\
\hline Intersep & 865.223 & 0.004 \\
HBER & 0.264 & $<0.000$ \\
THPPR & 0.001 & 0.714 \\
DPP & -0.050 & 0.007 \\
LHGTPR & 0.203 & 0.184 \\
\hline Prob $>$ F $:<0.0001$ & $\mathrm{R}^{2}: 0.954$ \\
DW:2.212 & & \\
\hline
\end{tabular}

Harga gabah di tingkat petani berhubungan positif dengan trend harga pokok pembelian pemerintah. Ketika pemerintah menetapkan harga pembelian pemerintah yang lebih tinggi maka harga gabah di tingkat petani juga meningkat, namun dengan respon yang inelastis baik dalam jangka pendek maupun jangka panjang. Meskipun pengaruh harga pembelian pemerintah tidak nyata secara statistik, namun harga pembelian pemerintah dapat dijadikan salah satu instrumen Bulog untuk menstabilkan harga gabah di tingkat petani dengan mengikuti trend harga yang selalu naik.

\section{Harga Impor Beras Indonesia}

Hasil estimasi persamaan harga impor beras Indonesia memiliki nilai $\mathrm{R}^{2}$ yang tinggi sebesar 0.96 (Tabel 6). Hal ini menunjukan bahwa sebesar 96 persen variasi harga impor beras Indonesia dapat dijelaskan oleh variabel-variabel harga beras dunia, nilai tukar, tarif impor beras Indonesia tahun sebelumnya dan harga impor beras Indonesia tahun sebelumnya. Harga impor beras Indonesia dari tahun 2004-2014 mencapai nilai tertinggi pada tahun 2011 yaitu sebesar US\$ 0.55/kg (USDA 2015).

Harga impor beras Indonesia berhubungan positif dengan harga beras dunia riil, tarif impor tahun sebelumnya, dan harga impor beras tahun sebelumnya tetapi berhubungan negatif dengan nilai tukar Indonesia riil. Harga impor beras tahun sebelumnya mempengaruhi harga impor beras Indonesia secara nyata, kondisi ini menunjukkan bahwa harga impor beras yang dilakukan memerlukan tenggang waktu yang lambat untuk kembali pada tingkat keseimbangannya. 
Tabel 6. Hasil Estimasi Parameter Harga Impor Beras Indonesia

\begin{tabular}{lrr} 
Variabel & $\begin{array}{r}\text { Parameter } \\
\text { Estimasi }\end{array}$ & Prob $>|t|$ \\
\hline Intersep & 0.226 & 0.271 \\
HBDR & 0.675 & 0.000 \\
NTR & -0.000 & 0.115 \\
LTIR & 0.000 & 0.729 \\
LHIBR & 0.400 & 0.000 \\
\hline Prob $>F:<0.0001$ & $\mathrm{R}^{2}: 0.965$ \\
DW: 2.52 & & \\
\hline
\end{tabular}

Harga impor beras Indonesia berhubungan positif dengan harga beras dunia riil, tarif impor tahun sebelumnya, dan harga impor beras tahun sebelumnya tetapi berhubungan negatif dengan nilai tukar Indonesia riil. Harga impor beras tahun sebelumnya mempengaruhi harga impor beras Indonesia secara nyata, kondisi ini menunjukkan bahwa harga impor beras memerlukan tenggang waktu yang lambat untuk kembali pada tingkat keseimbangannya.

\section{Harga Beras Eceran}

Persamaan harga beras eceran mempunyai nilai $\mathrm{R}^{2}$ yang tinggi sebesar 0.95 (Tabel 7). Hal ini menunjukan bahwa sebesar 95 persen variasi harga beras eceran dapat dijelaskan oleh harga impor beras Indonesia, harga gabah di tingkat petani, permintaan beras tahun sebelumnya dan harga beras eceran tahun sebelumnya.

Harga beras eceran Indonesia dari tahun 2004-2014 mencapai nilai tertinggi pada tahun 2012 yaitu sebesar US\$ $1.11 / \mathrm{kg}$ (BPS 2015). Harga beras eceran Indonesia berhubungan positif dengan harga impor beras Indonesia, harga gabah tingkat petani, permintaan beras, trend, dan harga beras eceran tahun sebelumnya tetapi berhubungan negatif dengan penawaran beras Indonesia tahun sebelumnya.
Tabel 7. Hasil Estimasi Parameter Harga Beras Eceran

\begin{tabular}{lrr} 
Variabel & $\begin{array}{c}\text { Parameter } \\
\text { Estimasi }\end{array}$ & Prob $>|t|$ \\
\hline Intersep & -2003.13 & 0.084 \\
HIBR & 37.964 & 0.756 \\
HGTPR & 2.015 & $<0.000$ \\
DB & 0.113 & 0.040 \\
LSB & -0.117 & 0.058 \\
LHBER & 0.423 & 0.009 \\
\hline Prob > F : <0.000 & $\mathrm{R}^{2}: 0.954$ \\
DW: 1.646 & & \\
\hline
\end{tabular}

Harga beras eceran Indonesia dipengaruhi secara nyata oleh harga gabah tingkat petani, permintaan beras, penawaran beras, dan harga beras eceran tahun sebelumnya. Harga gabah tingkat petani berpengaruh secara nyata.

Harga impor beras rill Indonesia berhubungan positif namun tidak nyata secara statistik. Hal tersebut karena transmisi harga beras Indonesia yang lemah sehingga perubahan harga impor tidak nyata berpengaruh terhadap perubahan harga eceran beras Indonesia. Harga beras eceran tahun sebelumnya mempengaruhi harga beras eceran Indonesia secara nyata, kondisi ini menunjukkan bahwa harga impor beras yang dilakukan memerlukan tenggang waktu yang lambat untuk kembali pada tingkat keseimbangannya.

\section{Hasil Validasi Model}

Model yang baik adalah model yang mampu menerangkan fenomena dunia nyata. Validasi model dalam penelitian ini mengacu pada indikator RMSPE dan U-Theil beserta dekomposisinya (Tabel 8).

Hasil validasi model menunjukkan bahwa sebagian besar (88.89 persen) variabel endogen memiliki nilai RMSPE kurang dari 20 persen. Nilai tersebut menunjukkan bahwa 88.89 persen nilai prediksi variabel endogen dapat mengikuti kecenderungan data historisnya dengan tingkat kesalahan 11.11 persen. Nilai koefisien Utheil dari masing-masing variabel endogen menunjukkan bahwa 
seluruh variabel endogen memiliki koefisien U-Theil dibawah nilai 0.15 . Hal ini menunjukkan bahwa persamaan di dalam model memiliki daya prediksi yang cukup baik dan valid untuk melakukan simulasi historis untuk periode 2010-2014 karena memiliki nilai dugaan yang cukup dekat dengan nilai aktual (lebih dari 85 persen).

Tabel 8. Hasil Validasi Model Permintaan dan Penawaran Beras Indonesia Tahun 20102014

\begin{tabular}{lrc}
\hline Variabel Endogen & $\begin{array}{c}\text { RMS \% } \\
\text { Error }\end{array}$ & $\begin{array}{c}\text { Koefisien } \\
\mathrm{U}\end{array}$ \\
\hline Luas areal panen & 1.676 & 0.008 \\
Produksi padi & 1.676 & 0.008 \\
Produksi beras & 1.676 & 0.008 \\
Stok beras Indone- & & \\
sia & 45.312 & 0.148 \\
Penawaran Beras & 2.262 & 0.012 \\
Harga gabah di & & \\
tingkat petani & 6.329 & 0.031 \\
Harga impor beras & 17.848 & 0.082 \\
Harga beras eceran & 15.301 & 0.066 \\
Permintaan Beras & 0.969 & 0.005 \\
\hline
\end{tabular}

\section{Dampak Perubahan Subsidi Pupuk}

Adanya kebijakan pemerintah dalam komoditas beras tentu akan berakibat pada perekonomian beras Indonesia. Kebijakan yang kerap dilakukan oleh pemerintah adalah subsidi pupuk urea. Peningkatan subsidi pupuk merupakan salah satu program pemerintah untuk memberikan insentif kepada petani agar meningkatkan produksinya. Peningkatan produksi padi diharapkan dapat memberikan kesejahteraan bagi petani dan dapat memberikan kesejahteraan kepada konsumen dengan harga yang terjangkau.

Skenario simulasi historis dalam penelitian ini adalah perubahan subsidi pupuk urea untuk mengevaluasi kebijakan pasar beras terhadap penawaran dan permintaan beras. Data yang digunakan adalah tahun 2010-2014. Skenario simulasi kebijakan dalam penelitian ini adalah peningkatan subsidi pupuk urea sebesar 10 persen. Variabel yang diubah adalah harga pupuk urea riil (HPUR) yang berkurang 10\% akibat adanya peningkatan subsidi pupuk tersebut. Hasil simulasi kebijakan subsidi pupuk urea disajikan pada Tabel 9.

Berdasarkan Tabel 9, hasil simulasi kebijakan penurunan subsidi pupuk urea sebesar 10 persen akan meningkatkan luas areal panen sebesar 0.1 persen. Peningkatan luas areal panen ini selanjutnya akan menyebabkan peningkatan produksi padi sebesar 0.1 persen atau setara dengan 13,900 ton. Peningkatan produksi padi akan diikuti peningkatan produksi beras sebesar 44,600 ton. Hal ini menyebabkan penawaran beras meningkat sebesar 0.1 persen atau setara 44600 ton.

Meningkatnya penawaran beras menyebabkan harga gabah di tingkat petani sebesar 0.01 persen. Hal ini berakibat pada menurunnya harga beras eceran. Harga beras eceran yang lebih murah direspon oleh konsumen sehingga permintaan beras meningkat 300 ton.

Pemerintah perlu memberikan jaminan harga kepada petani sehingga harga dapat dikendalikan pada kesetimbangan yang dapat menguntungkan petani. Program jaminan harga yang pemerintah lakukan berupa kebijakan Harga Pembelian Pemerintah (HPP). Oleh sebab itu dalam penelitian ini dilakukan simulasi peningkatan HPP yang diharapkan dapat memberikan keuntungan bagi produsen. 
Tabel 9. Hasil Simulasi Historis Peningkatan Subsidi Pupuk Urea 10\%, Tahun 2010 2014

\begin{tabular}{lcrrr}
\hline \multicolumn{1}{c}{ Variabel Endogen } & Satuan & Nilai Dasar & Nilai Simulasi & \% Perubahan \\
\hline Luas areal panen & ribu ha & 13561.8 & 13575.7 & 0.102 \\
\hline Produksi padi & ribu ton & 68959.5 & 69030.3 & 0.103 \\
\hline Produksi beras & ribu ton & 43444.5 & 43489.1 & 0.103 \\
\hline Stok beras Indonesia & ribu ton & 1561.6 & 1561.6 & 0.000 \\
\hline Penawaran Beras & ribu ton & 46394.4 & 46439.0 & 0.096 \\
\hline $\begin{array}{l}\text { Harga gabah di tingkat } \\
\text { petani }\end{array}$ & $\mathrm{Rp} / \mathrm{Kg}$ & 3923.6 & 3923.2 & -0.010 \\
\hline Harga impor beras & $\mathrm{US} \$ / \mathrm{Kg}$ & 0.5334 & 0.5334 & 0.000 \\
\hline Harga beras eceran & $\mathrm{Rp} / \mathrm{Kg}$ & 8571.9 & 8571.1 & -0.009 \\
\hline Permintaan Beras & $\mathrm{Ribu} \mathrm{ton}$ & 38233.7 & 38234.0 & 0.000 \\
\hline
\end{tabular}

Berdasarkan Tabel 10 dapat dilihat bahwa, jika Harga Pembelian Pemerintah (HPP) ditingkatkan sebesar $10 \%$ maka harga gabah tingkat petani akan meningkat. Harga gabah meningkat sebesar $0.5 \%$ atau setara dengan $\mathrm{Rp}$ $19,-/ K g$. Peningkatan harga gabah menjadi insentif bagi petani untuk meningkatkan produksi mereka, sehingga produksi padi meningkat sebesar $0.06 \%$ atau setara dengan 43,400 ton yang diikuti oleh peningkatan produksi beras sebesar 27,600 ton. Peningkatan produksi beras mengakibatkan penawaran meningkat sebesar $0.06 \%(28,000$ ton) beras eceran di pasar domestik meningkat sebesar $0.4 \%$ atau setara dengan $\mathrm{Rp} 37,-/ \mathrm{Kg}$.

Tabel 10. Hasil Simulasi Historis Peningkatan Harga Pembelian Pemerintah Sebesar 10\%, Tahun 2010 - 2014

\begin{tabular}{lcrrr}
\hline \multicolumn{1}{c}{ Variabel Endogen } & Satuan & Nilai Dasar & Nilai Simulasi & \% Perubahan \\
\hline Luas areal panen & ribu ha & 13561.8 & 13570.4 & 0.063 \\
\hline Produksi padi & ribu ton & 68959.5 & 69003.3 & 0.064 \\
\hline Produksi beras & ribu ton & 43444.5 & 43472.1 & 0.064 \\
\hline Stok beras Indonesia & ribu ton & 1561.6 & 1560.2 & -0.090 \\
\hline Penawaran Beras & ribu ton & 46394.4 & 46422.0 & 0.060 \\
\hline $\begin{array}{l}\text { Harga gabah di ting- } \\
\text { kat petani }\end{array}$ & $\mathrm{Rp} / \mathrm{Kg}$ & 3923.6 & 3942.9 & 0.49 \\
\hline Harga impor beras & $\mathrm{US} \$ / \mathrm{Kg}$ & 0.5334 & 0.5334 & 0.000 \\
\hline Harga beras eceran & $\mathrm{Rp} / \mathrm{Kg}$ & 8571.9 & 8609.0 & 0.433 \\
\hline Permintaan Beras & $\mathrm{Ribu}$ ton & 38233.7 & 38218.1 & -0.041 \\
\hline
\end{tabular}

Hasil ini sama dengan beberapa penelitian terdahulu yang menggunakan simulasi kenaikan harga dasar gabah. Hutauruk (1996) dan Nur (1999) menyatakan bahwa kebijakan kenaikkan harga dasar gabah akan meningkatkan produksi domestik dan meningkatkan harga beras. Sedangkan menurut Cahyono (2001), peningkatan harga dasar gabah akan meningkatkan produksi padi kecuali di luar Jawa tanpa Lampung. Sitepu (2002) juga menyimpulkan bahwa kenaikkan harga dasar gabah akan meningkatkan produksi padi dan distribusi pendapatan akan semakin baik.

Dampak peningkatan subsidi pupuk dan HPP terhadap peningkatan harga gabah juga mengakibatkan harga eceran yang meningkat direspon oleh konsumen dengan mengurangi permintaan mereka, sehingga permintaan di pasar domestik turun sebesar $0.04 \%$ atau setara dengan 15,600 ton. Kombinasi antara kebijakan peningkatan subsidi pupuk dan HPP sebesar 5\% dapat dilihat pada Tabel 11. 
Tabel 11. Hasil Simulasi Historis Kombinasi Kebijakan Peningkatan Subsidi Pupuk Urea $5 \%$ dan Peningkatan Harga Pembelian Pemerintah Sebesar 5\%, Tahun $2010-2014$

\begin{tabular}{lcrrr}
\hline \multicolumn{1}{c}{ Variabel Endogen } & Satuan & Nilai Dasar & Nilai Simulasi & \% Perubahan \\
\hline Luas areal panen & ribu ha & 13561.8 & 13573.1 & 0.083 \\
\hline Produksi padi & ribu ton & 68959.5 & 69016.8 & 0.083 \\
\hline Produksi beras & ribu ton & 43444.5 & 43480.6 & 0.083 \\
\hline Stok beras Indonesia & ribu ton & 1561.6 & 1560.9 & -0.045 \\
\hline Penawaran Beras & ribu ton & 46394.4 & 46430.5 & 0.078 \\
\hline $\begin{array}{l}\text { Harga gabah di ting- } \\
\text { kat petani }\end{array}$ & $\mathrm{Rp} / \mathrm{Kg}$ & 3923.6 & 3933.0 & 0.240 \\
\hline Harga impor beras & $\mathrm{US} \$ / \mathrm{Kg}$ & 0.5334 & 0.5334 & 0.000 \\
\hline Harga beras eceran & $\mathrm{Rp} / \mathrm{Kg}$ & 8571.9 & 8590.1 & 0.212 \\
\hline Permintaan Beras & $\mathrm{Ribu}$ ton & 38233.7 & 38226.0 & -0.020 \\
\hline
\end{tabular}

\section{Kesejahteraan Produsen dan Kon- sumen Beras}

Beberapa instrumen kebijakan perberasan yang dilakukan pemerintah untuk menjamin kesejahteraan masyarakat meliputi jaminan harga dan subsidi input salah satunya subsidi pupuk. Kebijakan peningkatan subsidi pupuk (simulasi 1) memberikan keuntungan bagi konsumen tetapi merugikan produsen (Suryana et al. 2016). Siswanto (2017) juga mengemukakan bahwa hasil pendugaan model persamaan simultan menunjukkan bahwa perubahan yang diakibatkan oleh penerapan kebijakan tunggal hanya meningkatkan kesejahteraan salah satu pihak sehingga tidak memberikan asas keadilan bagi konsumen dan produsen. Tabel 12 menunjukkan bahwa peningkatan subsidi pupuk menyebabkan meningkatnya produksi padi, namun dengan meningkatnya produksi padi mengakibatkan harga gabah turun sehingga merugikan petani. Kerugian petani terlihat dari penurunan surplus produsen sebesar Rp 17,368.88 milyar. Hal ini menunjukkan bahwa peningkatan produksi padi domestik tidak dapat mengkompensasi penurunan harga gabah.

Berbeda dengan produsen, penurunan harga gabah mengakibatkan turunnnya harga eceran sehingga meningkatkan permintaan beras di pasar domestik. Kondisi ini memberikan keuntungan bagi konsumen terlihat dari surplus konsumen sebesar Rp 30,586.84 milyar. Penerapan kebijakan tunggal berupa subsidi pupuk tidak dapat meningkatkan kesejahteraan petani, padahal kebijakan tersebut ditujukan kepada petani untuk meningkatkan produksi padi sehingga keuntungan petani bertambah. Produksi padi meningkat namun harga jual gabah menurun, sehingga bukan keuntungan tetapi kerugian yang diterima petani. Kondisi ini menunjukkan bahwa penerapan jaminan harga sangat diperlukan bagi petani untuk meningkatkan kesejahteraannya. Kebijakan peningkatan subsidi pupuk cukup efisien karena net surplus masih bernilai positif (Rp 13,217.96 milyar), kerugian produsen dan pemerintah masih mampu ditutupi oleh surplus konsumen. 
Tabel 12. Dampak Perubahan Subsidi Pupuk Urea dan HPP terhadap Kesejahteraan Produsen dan Konsumen Beras di Indonesia Tahun 2010-2014

\begin{tabular}{lrrr} 
& \multicolumn{3}{c}{ (Rp. Milyar) } \\
\cline { 2 - 4 } Perubahan Komponen & \multicolumn{3}{c}{ Simulasi } \\
Kesejahteraan & S1 & S2 & S3 \\
\hline Surplus Produsen & $-17,768.88$ & $838,212.51$ & $408,208.63$ \\
Surplus Konsumen & $30,586.84$ & $-1,418,759.65$ & $-695,923.41$ \\
\hline \multicolumn{1}{c}{ Net Surplus } & $13,217.96$ & $-580,547.14$ & $-287,714.78$ \\
\hline
\end{tabular}

S1: peningkatan subsidi pupuk urea $10 \%$

S2: peningkatan HPP $10 \%$

S3: peningkatan HPP 5\% dan subsidi pupuk urea 5\%

Kebijakan jaminan harga berupa peningkatan Harga Pembelian Pemerintah (simulasi 2) mengakibatkan peningkatan harga gabah, sehingga menjadi insentif petani untuk meningkatkan produksi padi. Peningkatan harga gabah dan produksi padi memberikan keuntungan bagi produsen yang terlihat pada surplus produsen sebesar Rp 838,212,51 milyar. Berbeda dengan produsen, peningkatan HPP mengakibatkan harga gabah meningkat sehingga harga eceran meningkat walaupun penawaran beras meningkat. Peningkatan harga gabah lebih efektif mempengaruhi harga beras eceran dibandingan dengan peningkatan penawaran beras. Peningkatan harga beras eceran mengakibatkan permintaan beras menurun. Kondisi ini mengakibatkan konsumen merugi yang terlihat pada menurunnya surplus konsumen sebesar Rp 1,418,759.65 milyar.

Kebijakan penjaminan harga berupa peningkatan Harga Pembelian Pemerintah (HPP) efektif untuk meningkatkan kesejahteraan produsen, tetapi menjadi tidak efektif untuk meningkatkan kesejahteraan konsumen beras. Kebijakan peningkatan Harga Pembelian Pemerintah (HPP) tidak efektif dan efisien dilakukan karena net surplus bernilai negatif ( $\operatorname{Rp} 580,547.14$ milyar), kerugian konsumen tidak mampu ditutupi oleh surplus produsen.

Kebijakan domestik berupa peningkatan HPP dan subsidi pupuk memiliki efek yang berbeda terhadap surplus produsen dan konsumen. Peningkatan HPP memberikan keuntungan bagi produsen tapi merugikan konsumen, sedangkan kebijakan subsidi pupuk memberikan keuntungan bagi konsumen tetapi merugikan produsen. Hal ini menunjukkan bahwa penerapan kebijakan tunggal tidak mampu memberikan keuntungan bagi kedua belah pihak.

Alternatif paket kebijakan berupa peningkatan Harga Pembelian Pemerintah (HPP) dan peningkatan subsidi pupuk (simulasi 3). Peningkatan subsidi pupuk memberikan insentif bagi petani untuk meningkatkan produksi padi, sedangkan peningkatan Harga Pembelian Pemerintah (HPP) mengakibatkan meningkatnya harga gabah di tingkat petani kondisi ini memberikan keuntungan bagi produsen terlihat dari surplus produsen sebesar Rp 408,208.63 milyar. Alternatif paket kebijakan sesuai dengan simulasi 3 dapat memberikan keuntungan bagi produsen maupun konsumen beras sehingga kesejahteraan petani dan konsumen beras meningkat. Pemerataan kesejahteraan tersebut merupakan kondisi yang diinginkan kedua pihak, sehingga harus menjadi pondasi utama bagi pemerintah untuk membuat kebijakan yang memihak semua lapisan masyarakat.

\section{SIMPULAN}

Kebijakan subsidi pupuk mengakibatkan penawaran beras domestik meningkat sehingga harga beras eceran turun. Penawaran meningkat diikuti dengan turunnya harga eceran mengakibatkan permintaan meningkat. Tetapi peningkatan permintaan lebih kecil dibandingkan peningkatan penawaran sehingga terjadi exces supply di pasar beras domestik. 
Kebijakan peningkatan Harga Pembelian Pemerintah (HPP) berdampak pada meningkatnya harga eceran beras domestik. Peningkatan harga eceran tersebut mengakibatkan permintaan turun. Tetapi penawaran tetap naik karena produksi beras domestik meningkat.

Surplus produsen dan surplus konsumen dipengaruhi oleh kondisi pasar beras domestik. Surplus produsen akan dicapai jika pemerintah menerapkan kebijakan jaminan harga berupa peningkatan Harga Pembelian Pemerintah (HPP), sedangkan surplus konsumen akan dicapai jika pemerintah menerapkan kebijakan peningkatan subsidi input berupa kredit pertanian dan subsidi pupuk serta peningkatan produktivitas areal. Untuk meningkatan surplus produsen dan konsumen secara merata maka perlu diterapkan paket kebijakan yang merupakan kombinasi dari kebijakan subsidi pupuk dan kebijakan HPP.

\section{DAFTAR PUSTAKA}

Anonim. 2019. https://ekonomi.kompas. $\mathrm{com} / \mathrm{read} / 2018 / 10 / 23 / 150000826 / \mathrm{sa}$ h-dpr-setujui-anggaran-2019-kementan-sebesar-rp-21-1-triliun-

Cahyono, S.A. 2001. Analisis Penawaran dan Permintaan Beras di Provinsi Lampung dan Kaitannya dengan Pasar Beras Domestik dan Internasional. Tesis. Sekolah Pascasarjana. Institut Pertanian Bogor.

Herman, A.S., Djumarman, dan H. Sukesi. 2005. Kajian Sistem Distribusi Pupuk Bersubsidi. Laporan Penelitian. Badan Penelitian dan Pengembangan Perdagangan, Jakarta.

Hutagaol, P., W.R. Susila, dan S. Hartoyo. 2009. Evaluasi Dampak Bantuan Langsung Benih Unggul dan Pupuk terhadap Usaha Tani dan Pengembangan Pedesaan. Laporan Penelitian, Fakultas Ekonomi dan Manajemen, Institut Pertanian Bogor.

Hutauruk J. 1996. Analisis Kebijakan Harga Dasar Padi dan Subsidi Pupuk Terhadap Permintaan dan Penawaran
Beras di Indonesia. Tesis. Sekolah Pascasarjana. Institut Pertanian Bogor.

Koutsoyiannis. 1977. Theory of Econometrics: An Introductory Exposition of Econometric Methods. Second Edition. London (UK): The MacMillan Press Ltd.

Nugroho, B.G. 2014. Dampak Tarif Impor Terhadap Produksi dan Impor Kedelai di Indonesia. Skripsi. Institut Pertanian Bogor

Nur, M. 1999. Analisis Penawaran Output dan Permintaan Input Tanaman Pangan Lahan Kering di Provinsi Lampung (Pendekatan Multi-Input Multi-Output). Ttesis. Sekolah Pascasarjana. Institut Pertanian Bogor.

Pindyck, R.S., D.L. Rubinfeild. 1991. Econometric Models and Economic Forecasts. Third Edition. New York (US): McGarw-Hill Inc.

PSE-KP (Pusat Analisis Sosial Ekonomi dan Kebijakan Pertanian). 2006. Konstruksi Kebijakan Pupuk 2006. PSE-KP, Bogor.

PSE-KP (Pusat Analisis Sosial Ekonomi dan Kebijakan Pertanian). 2009. Pengalihan Subsidi Pupuk ke Subsidi Benih, Analisis Kebijakan. PSE-KP, Bogor.

Siswanto, E. 2017. Dampak Kebijakan Perberasan Terhadap Pasar beras dan Kesejahteraan Produsen dan Konsumen Beras di Indonesia. Tesis. Sekolah Pascasarjana. Institut Pertanian Bogor.

Sitepu, R. K. dan B. M. Sinaga. 2006. Aplikasi Model Ekonometrika: Estimasi, Simulasi, dan Peramalan Menggunakan Program SAS. Program Studi Ilmu Ekonomi Pertanian, Sekolah Pascasarjana, Institut Pertanian Bogor, Bogor.

Sitepu, R.K. 2002. Dampak Kebijakan Ekonomi dan Liberalisasi Perdagangan terhadap Penawaran dan Permintaan Beras di Indonesia Tesis. Sekolah Pascasarjana. Institut Pertanian Bogor.

Sjari, D.R. 2007. Pengaruh Subsidi Harga Pupuk terhadap Pendapatan Petani: Analisis Sistem Neraca Sosial Ekonomi. Bank Indonesia, Jakarta. http://www.bi.go.id [4 Mei 2019]. 
Suryana, A.J., Winoto, B. Krisnamurthi dkk. 2001. Bunga Rampai Ekonomi Beras. Lembaga Penyelidikan Ekonomi dan Masyarakat Fakultas Ekonomi, Universitas Indonesia, Badan Bimas Ketahanan Pangan Departemen Pertanian dan Badan Perencanaan Pembangunan Nasional, Jakarta.

Syafa'at, N., A. Purwoto, M. Maulana, dan C. Muslim. 2006. Analisis Besaran Subsidi Pupuk dan Pola Distribusinya. Laporan Akhir Penelitian,
Pusat Analisis Sosial Ekonomi dan Kebijakan Pertanian, Bogor.

Widarjono, A. 2007. Ekonometrika Teori dan Aplikasi untuk Ekonomi dan Bisnis. Yogyakarta (ID): Ekonisia.

World Bank. 2009a. Fertilizer Subsidies in Indonesia, Policy Note. Indonesia Agriculture Public Expenditure Review, the World Bank, Jakarta.

World Bank. 2009b. Indonesia Agricultural Public Spending and Growth, Policy Note. Indonesia Agriculture Public Expenditure Review, the World Bank, Jakarta. 